\title{
Research on the Status Quo and Countermeasures of Campus Culture Construction in Agricultural Universities and Colleges
}

\author{
Yuci Wang \\ Beijing University of Agriculture \\ Beijing 102206
}

\begin{abstract}
The construction of campus culture in agricultural colleges and universities is the need to improve students conscious ness of "agriculture, rural are as and farmers". It plays the role of guiding, standardizing, motivating and agglome rating the students' growth and helps to cultivate the enthusiasm and enthusiasm of the students to study agricultural majors, and improve the humanistic spirit and cultural atmosphere of agricultural colleges and universities. This paper analyzes the significance, status quo and existing problems of campus culture construction in agricultural colleges and universities, and puts forward the countermeasures to improve the campus culture construction of agricultural colleges and universities, namely, the cons truction of campus culture should reflect the orientation of running a school and the philosophy of running a school, we must build a harmonious campus culture in all directions in all directions, face the society and strengthen school-enterprise cooperation, and we must use new media to give full play to the positive energy of network culture.
\end{abstract}

Keywords-agricultural Colleges and universities; campus culture; current situation; countermeasures

\section{INTRODUCTION}

Campus culture is an important part of higher education, an important part of talent cultivation, and an important platform to demonstrate the school's philosophy of running schools and school characteristics. Strengthening the construction of campus culture in colleges and universities is of great significance to deepening the teaching reform of higher education, comprehensively improving the quality of talents, promoting the development of schools, and making all-round social progress.

\section{Significance of Campus Culture Construction in AgRicultural UNIVERSITIES AND COLLEGES}

A. The need to improve the students' consciousness of "issues of agriculture, rural areas and farmers"

China is a large agricultural country. The development of agriculture is an important way to promote national economic development and social stability. The agricultural colleges and universities are the gathering place for talents of "agriculture, rural areas and farmers" and the commanding points for the "agriculture, rural areas and farmers" scientific and technological level and shoulder the mission of serving "agriculture, rural areas and farmers", cultivating talents of "agriculture, rural areas and farmers", and are responsible for the new rural construction and the advancement of social civilization. However, due to the influence of traditional prejudices, agricultural colleges and universities do not attach enough importance to agricultural culture in higher education. Students in agricultural colleges and universities are treated unfairly in terms of employment and social activities, resulting the weak consciousness of "emphasizing agriculture, engaging in agriculture, approaching to agriculture and loving agriculture". Some students dare not show their identity in public places, and even minimize contact with farmers in campus cultural activities. It is of great significance for cultivating outstanding agricultural and forestry talents with the spirit of innovation and dedication to meet the needs of socialist modernization by strengthening the construction of campus culture, actively promoting the dissemination of agricultural culture, cultivate students' awareness of "emphasizing agriculture, engaging in agriculture, approaching to agriculture and loving agriculture" and increasing teachers and students' feelings about "agriculture, rural areas, and farmers". [1]

\section{B. Guide, regulate, encourage and consolidate students' growth and success}

Campus culture is the spirit of the university, which affects students in a subtle manner. The construction of a campus culture with agricultural characteristics will help guide the growth and development of students. The various rules and regulations in the campus culture stipulate what the students can do and what they cannot do, helping maintain the normal teaching order and promoting students to develop civilized learning and living habits. Excellent campus culture has the influence like life-giving spring breeze, purifies the mind, cultivates sentiments, unites people, advances people, motivates students to be positive and ambitious, inspires students to participate in learning with passion and learns and progresses constantly under the influence of culture. The active and civilized campus culture can present teachers and students' outlook on life, values, ideals, and behaviors, and unite them together to enhance the sense of identity, pride and collective honor between teachers and students. [2] 


\section{Help students develop enthusiasm for studying agricultural major}

Due to the influence of traditional and realistic environments, many students are reluctant to apply for admission to agricultural colleges and universities, which results in difficulty in enrolling students in agricultural colleges and universities. The enrollment line is about 30 points lower than that of universities at the same level. Some students still have varying degrees of resistance to and rejection of agriculture after entering the school, leading to the lack of enthusiasm, insufficient energy devoted to professional learning and confusion for the future. Some students try everything they can to transfer major and transfer schools. Strengthening the construction of campus culture in agricultural colleges and universities will help show China's long-standing agricultural culture, enhance students' understanding of the importance and urgency of China's agricultural development, cultivate students' enthusiasm and interest, and build their confidence and enthusiasm for studying agricultural majors. [3]

\section{Help improve the humanistic spirit and cultural atmosphere of agricultural colleges and universities}

Although the subjects of agricultural colleges and universities have diversified development, agriculture is the main part and liberal arts majors are still very weak. Owing to lack of humanistic spirit, weak cultural atmosphere and serious impact of utilitarianism on schools, students' humanistic spirit and ideological qualities need to be enhanced. The school should strengthen the construction of campus culture, allow students to nurture through the culture of agriculture, enhance their own humanistic spirit and ideological quality, and help students form a perfect personality and moral character, thus providing intellectual support for the cultivation of high-quality talents in agriculture and forestry.

\section{THE STATUS QUO AND PROBLEMS OF CAMPUS CULTURE CONSTRUCTION IN AGRICULTURE UNIVERSITIES AND COLLEGES}

\section{A. Unclear positioning of campus culture}

After the agricultural colleges and universities are upgraded or rebuilt, the education and teaching mode has not been completely changed by the influence of traditional ideas. The orientation of the campus culture is too low or not clear. It can not embody its own school features, or even blindly imitate the recreational community to carry out the sports activities of the campus, pursue the number of activities and ignore the needs of students and the actual situation of schools. Campus culture is not equal to the form of fancy mass entertainment, nor is it a multitude of club activities. It is the spirit of the university and the experience and influence that the participation activities bring to teachers and students.

\section{B. Insufficient understanding of campus culture construction}

Agricultural colleges and universities, like other comprehensive schools, overemphasized the improvement of the school's hardware environment and neglected the construction of campus spiritual culture, resulting in the inability of campus culture to play its due role in the process of upgrading and expanding the school. Owing to insufficient understanding of campus culture, the spiritual and cultural factors in the material construction have been neglected; the school's philosophy of running school and the overall characteristics of school characteristics are not combined and cultural influence is neglected. In addition, agricultural colleges and universities just earnestly implement and strictly manage the rules and regulations but ignore the recognition of teachers and students to the system and the system's subjective influence on teachers and students and fail to establish a harmonious institutional culture. Some school leaders do not pay enough attention to campus culture, do not see the profound influence of campus culture on the development of colleges and universities, lack rational thinking about campus culture, and have no overall consideration on the values, mode of thinking, cultural form, code of conduct, cultural environment and system standards of campus culture and a unified consensus on material culture, institutional culture, behavior culture and spiritual culture in schools.

\section{Inadequate expression of agricultural culture and lack of features in the mainstream of culture}

With the leap-forward development of higher education, the development of disciplines in colleges and universities presents a diversified trend. Single-university universities develop into comprehensive universities through enrollment expansion or merger. Due to the influence of traditional concepts, there are prejudices in the society for colleges and universities characterized by agriculture, forestry, land, minerals, oil, and water. It's difficult for these colleges and universities to recruit students. Their admission score must be much lower than the scores for college admissions at the same level. For the sake of development, some colleges and universities with agricultural, forestry, land, mineral, oil, and water names are trying their best to change their names and add new majors to improve their student conditions. The colleges and universities featuring agriculture, forestry, land, minerals, oil, and water have all been renamed as universities that are popular in science and technology, science and engineering, industry, economy, and engineering, and the original school name reflecting the characteristics and advantages of the school has disappeared. As agricultural colleges and universities, there is no agriculture covered in school ethos and no agriculture presented in school education. Under the impact of various social ideological trends, the mainstream culture of "emphasizing agriculture, engaging in agriculture, approaching to agriculture and loving agriculture" has gradually disappeared, and individual colleges and universities have gradually lost their agricultural culture. [4]

\section{The lack of external communication between campus culture construction}

The construction of campus culture only pays attention to the internal cultural construction. For reasons such as capital shortage, student safety, and organizational difficulty, the main body of campus culture is limited to the teachers and students in the school. The absence of external corporate and offcampus personnel in the campus culture makes students less exposed to the society, and it is difficult to understand the society and adapt to the society. The local government or enterprises cannot play a supporting role in the campus culture. 
The little communication between school and the outside world makes the campus culture difficult to get social recognition and is not conducive to the sustainable development of campus culture.

\section{E. Impact of construction of campus by the network culture}

The arrival of the information age has had a profound impact on institutions of higher learning. On the one hand, the popularization of WeChat, Microblog, mobile phones, and the Internet has greatly facilitated people's lives, accelerated the speed of information dissemination, and broadened the students' horizons and knowledge. In addition, its combination with material culture has improved the material and cultural level of the campus. On the other hand, in the age of information, Western values and worldviews are more easily communicated and infiltrated by students through the Internet. The positive energy of socialist core values is impacted by Western values and worldviews. Some students are addicted to the fun brought by the Internet and even go out of bed, which affects normal learning and life. Some violence, pornography, and reactionary content on the Internet will have a bad influence on some students with poor self-control. They will experience negative emotions such as mental stress, depression, anger and depression, and even subvert the university students' outlook on world, life and values. Therefore, the construction of campus culture has been affected by the Internet culture and shows an inconsistent aspect.

\section{STRATEGIES TO IMPROVE THE CONSTRUCTION OF CAMPUS} CULTURE IN AGRICULTURAL COLLEGES AND UNIVERSITIES

\section{A. Campus culture construction should embody the orientation of running a school}

The construction of campus culture should be guided by the school's orientation and development plan, and pay attention to the cultural elements of superior disciplines and specialties. In the long-term practice, Beijing University of Agriculture upholds the fine tradition of "hard work, diligence in practice, advocating science, and facing the grassroots," and has established a school-running position of "founding itself in the capital, serving the countryside, and radiating the whole country." The Beijing Agronomy College's secondary colleges hold various cultural festivals according to their own characteristics. The College of Animal Sciences, in conjunction with the pet culture festival carried out by the animal science and animal medicine specialties, is committed to "caring for animals and creating harmony”, helping teachers and students understand animals better and loving animals, and advocating the school teachers and students to "love animals, respect life, save in everyday life and start from scratch." The pet cultural festival provides college students with a platform for selfexpression and mutual exchange, and builds a cultural brand that belongs to the Academy of Sciences. The garden culture festival is a combination of gardening, forestry, and tourism major, has carried out a series of cultural activities, such as "Joint Spring Visit for the Culture of Flower Appreciation" activity, "Exhibiting Garden Style, Purchasing New Life" Exhibition of thematic works, "Plants Change Lives and Learning Create the future" - knowledge contests for garden plants, "Read A Splendid Culture and Travel Beautiful Rivers and Mountains" - knowledge of tourism culture and so on.

\section{B. Campus culture construction should embody the philosophy of running a school}

Beijing University of Agriculture has been established since 1956. In the course of 62 years of development, it has formed the school-training spirit of "great kindness and sincere behaviour as well as erudition and advocation of agriculture" and the "agricultural-oriented and practically new" concept. Beijing University of Agriculture aims at cultivating talents with innovative application and modern entrepreneurial abilities in modern agriculture and forestry, and strives to create and improve a metropolitan modern agricultural higher education system. The school adheres to the concept of "people-oriented education and moral education first" and embarks on quality education, science and technology competitions and a variety of cultural and sports activities. The construction of campus culture reflects the agricultural-based concept of running a school. For example, on the Beijing University of Agriculture "agriculture, rural areas and farmers" cultural exhibition, the secondary colleges combine professional features with texts, pictures, and objects in various forms to display the "agriculture, rural areas and farmers" of the East China, South China, Central China, North China, Northwest, Southwest, Northeast, Hong Kong, Macao and Tai wan, including local characteristics of agricultural activities, agricultural products, agricultural development status and so on

\section{Multi-channel construction of a harmonious campus culture}

It is necessary to attach importance to the construction of material culture and to promote the comprehensive development of spiritual culture, behavior culture and system culture when taking various channels and multiple directions to construct campus culture. The first is to nurture the campus spirit of agricultural themes, starting from school training, school songs, school spirit, school philosophy, and the orientation of running schools. This is the soul of campus culture and subtly influences school development. The second is to cultivate institutional culture with agricultural characteristics. In the various regulations, systems, management methods, and guidelines, it is necessary to have the characteristics of ordinary colleges and universities, but also to reflect the characteristics of agricultural colleges and universities to ensure the normal operation of agricultural colleges and universities. The third is to carry out cultural activities with agricultural characteristics. Based on the cultivation of agricultural talents, we will carry out various forms of cultural activities based on professional characteristics. For example, the Food Culture Festival conducted by the Food Institute stimulates students' interest in the research and development of new food products, establishes food safetybased business concepts, and provides students with a platform for practical exercise and display. The fourth is to build a campus landscape with agricultural characteristics. The North Agricultural Science and Technology Park, thousands of mu Farm and tens of thousands of mu Forest Farm established by Beijing University of Agriculture reflect the great importance of the school to material culture. The school's roads are marked 
with Chinese parasol Road, Yulan Road, and Ginkgo Road. The campus is full of trees and bustling and weeds are everywhere. Teachers and students can feel the influence of agricultural culture in every corner of the school. The fifth is the establishment of student societies with agricultural characteristics. For example, A Corner of the World gardening club established by Beijing University of Agriculture provides micro-landscape production, popularization of plant cultivation knowledge and planting exchanges, which provides a platform for student exchanges and promotes the cultural concept of love for the environment. The sixth is to strengthen the school history education, publicize the school history culture, and enhance teachers and students' feelings towards the school. Through school history exhibition, school history activities, and school celebration activities, it promotes the school's long history of running schools and agricultural culture, and enhances the feelings of teachers and students in loving schools and agriculture. Beijing University of Agriculture pays attention to constructing campus culture in an all-round way through multiple channels. It has been awarded the title of Beijing Garden-styled Unit, Beijing Civilized Campus, Capital Civilized Unit Model, and National Civilized Unit and so on. In 2014, it won the second prize for Outstanding Achievement in the Construction of National Campus Culture.

\section{Campus culture should facing society and strengthen school-enterprise cooperation}

Schools should combine the internal construction of campus culture with external coordination, go deep into the enterprise, strengthen communication and cooperation with the enterprise, introduce the company's positive culture into the school, allow students to understand the meaning of the corporate culture, and lay a foundation for the students to step into the job position. In addition, Schools should also collaborate with external units to train students and reflect the openness and practicality of campus cultural construction in colleges and universities. Beijing Agricultural College has explored new mechanisms for joint training of talents with governments, enterprises, research institutes, and agricultural and forestry colleges at home and abroad. It adhered to the principle of "facing the world and opening school", and continuously expanded the field of international cooperation in running schools. It has signed cooperation agreements with more than 30 foreign universities. Among them, the SinoBritish Joint Education Project has been fully affirmed by the Quality Assurance Agency for Higher Education in the UK. The Sino-Australian Joint Education Project has successfully passed the evaluation of the Ministry of Education and has conducted joint training with relevant universities in the United States, the United Kingdom, and New Zealand. The school also actively establishes partnerships with employers for schoolenterprise partnerships, conducts more than 170 practical training bases and practice bases, builds a practice platform for students, improves the overall quality of students, and achieves zero distances between students and enterprises.

\section{E. Utilize new media to play a positive role in network culture}

In the information-based context, various new media emerge in an endless stream, including online media such as microblogs, blogs, website forums, search engines, and online newspapers and magazines, as well as mobile media like mobile phone APPs, WeChat, and text messages. Schools can use a variety of resources to create a platform for teacherstudent exchanges and promote campus culture. Teachers and students, through online media and mobile media, can understand the significance of campus cultural construction and actively participate in campus culture construction. The new media can be used to harness the positive energy of the Internet culture, and socialist core values education can be conducted to positively inspire and guide students. Beijing University of Agriculture disseminates all kinds of information at the fastest speed through the school's official website, official WeChat, official microblog, campus BBS, BUA information platform, and campus community websites. Teachers and students speak freely through new media, which have enhanced communication and exchanges between them. Under the background of network culture, the main body of new media communication is diversified, means are diversified, dissemination time is more powerful, and communication content is richer. Therefore, the positive energy of the network culture played by the new media has broken the wall inside and outside the school, expanded the space of campus culture, and added vitality to the campus culture.

\section{CONCLUSIONS}

The construction of campus culture in agricultural colleges and universities must be combined with their own schoolrunning orientation and school-running philosophy, and adopt multi-channel and all-round measures to construct campus culture. We must face society, strengthen school-enterprise cooperation, and reflect the openness and practicality of campus culture. Under the informational background, we must actively use new media and bring into play the positive energy of the Internet culture so as to expand the construction space for campus culture.

\section{REFERENCES}

[1] Wang Gangqing, Wang Yannian, Gao Yan, et al. Exploration and Thinking of Campus Culture Construction in Higher Agricultural Universities and Colleges[J]. Higher Agricultural Education, 2009,5(5):3-5.

[2] Hu Siying, Bai Hongliang. An Analysis of Campus Culture Construction in Higher Agricultural Universities and Colleges[J]. Ideological and Political Education Research, 2013, 29(4):90-92.

[3] Xiong Fuqiang, Tan Hao, Sheng Xin, et al. Research on the Status Quo and Approaches of Campus Culture Construction in Higher Agricultural Universities and Colleges[J].China Electric Power Education,2013(19):223-224.

[4] Xu Zhiyong, Cui Fenghua, Liu Hui, et al. Discussion on Traditional Dominant Disciplines and Construction of Campus Culture in Agricultural Universities and Colleges[J].Heilongjiang Agricultural Science, 2012(5):135-138. 